\title{
ECONOMICS OF POULTRY MANURE AS AN ALTERNATIVE TO CHEMICAL FERTILIZER FOR AGRICULTURAL PRODUCTION IN NEPAL
}

\author{
S. Subedi and D. Dhakal \\ Institute of Agriculture and Animal Sciences, Tribhuvan University, Nepal
}

\begin{abstract}
This paper explored the potentiality of poultry manure to use as fertilizer in agricultural practices through using descriptive statistics and probit regression model. Result showed that Poultry manure was comparatively more economical than chemical fertilizers regarding same amount of NPK availability for crop production. Sampled households' age, income, agriculture as main occupation, credit access and membership had significantly determined the level of the application of poultry manure. Farmers perceived that affordable price and soil fertility improvement were the main reasons behind applying it. However, volatization, leaching, improper decomposition, poor market infrastructure and transportation and branding were identified as the major problems associated with its use. Study also revealed that willingness to pay for processed poultry manure was 4 to 7 times higher than what farmers were paying for raw poultry manure. Therefore, either the government or private firms should take initiative in production of processed poultry in Nepal.
\end{abstract}

Key words: Poultry manure, Agriculture, Probit regression, Indexing, Willingness to pay

\section{INTRODUCITON}

Agriculture is a major component of the Nepalese economy where the majority of the population, about $66 \%$ of the active population, are engaged in this sector for their livelihood. It has significant role in Gross Domestic Product (GDP) but with the share of around only 35\% (MOAD, 2012). Further, many rural livelihood depend upon subsistence based agriculture (Samriddhi, 2011). A livestock component, which shares around 26\% AGDP, is an integral part of Nepalese farming system (MOAD, 2012). Poultry is one of the important emerging sub-sectors of livestock in recent Nepal.

Fertilizer plays a very important role to increase yield of agriculture crops. However, fertilizer in the Nepalese agricultural context has always been a political commodity; supplying of chemical fertilizers as per demand has always been a big challenge for the government. The demand for chemical fertilizers is found to be increasing by over 15 percent per year while the supply is in deficit by $46 \%$ over the same period (AICL, 2012). Although, the fertilizer deficit situation exists in Nepal, it is not feasible to establish inorganic fertilizer factory in the country. Lack of raw materials such as naptha, petroleum, coal, natural gas and phosphates in Nepal, being the first reason followed by inadequate electric power and comparatively lower domestic demand than other countries, as second and third reason respectively (Thapa, 2006).Continuous use of chemical fertilizer does not replenish the soil nutrients regularly, instead it exhausts the soil fertility and decreases the nutrient availability to the crop. A study carried out in the mid-hills of Nepal revealed 20 tons per ha of soil loss per year with a huge amount nutrient loss; $300 \mathrm{~kg}$ of organic matter, $15 \mathrm{~kg}$ of nitrogen, $60 \mathrm{~kg}$ of phosphorus and $40 \mathrm{~kg}$ of potash were lost (Tripathi, 2002).

Organic farming has been recognized as the most widely accepted alternative farming system for sustainable production with the promotion of environmental health and ecology. In addition to this, organic agriculture plays a significant role in providing food and income (Sharma, 2001). 
Poultry manure is an important nutrient source to increase the yield of the crop. As compared to the manure from other animals, poultry manure has greater concentration of the nutrients required for plant growth; it is rich organic manure, since liquid and solid excreta are excreted without loss of urine (Ewulo, 2005). It is estimated that the poultry sub sector has been growing at a rate of 10 per cent per annum over the last decade (Ryan and Pant, 2011). The commercial poultry population reached 85.5 million including broilers and layers across the nation in 2011; they produce million of tons of manure (Bhattarai, 2012 a).

Though there is a practice of using the unprocessed poultry manure in Nepal for agricultural production, a large fraction of nutrients such as nitrogen, phosphorus and potassium are lost by leaching and volatization. Economic recycling of the poultry manure could conserve and with added nutrients making it more valuable and useful for agricultural production. This will also reduce the adverse environmental impacts of this large quantity of degradable waste produced by poultry industries in Nepal. With this background the main objective of this paper is to explore the potentiality of poultry manure to substitute chemical fertilizers in the existing chemical fertilizer supply deficit situation of Nepal.

\section{METHODOLOGY}

\section{Study area, sample size and data collection technique}

Two Village Development Committees (VDCs) of Chitwan district of Nepal, Mangalpur and Fulbari were purposively selected. Chitwan district was selected because of the well established poultry industry as compared to other districts of Nepal and Mangalpur and Fulwari VDCs were selected because of intensive use of poultry manure for agricultural production in these VDCs as compared to other VDCs of Chitwan as identified by pilot survey and information received through DADO, Chitwan. A total of 120 households, 60 from each VDC of which 30 were poultry manure user and 30 non-users, were selected using purposive random sampling technique. Primary data were collected through a pre-tested interview schedule, focus group discussions and key informant interviews. Secondary data were collected from relevant publication of government offices such as Department of Agriculture, Central Bureau of Statistics, National Planning Commission, Food and Agriculture Organization (FAO).

\section{Comparative assessment of economics of using poultry manure and chemical fertilizer in agricultural production}

Use of poultry manure in agriculture is supposed to be a potential substitute for chemical fertilizers. A comparative assessment on nutrient availability and cost incurred in using poultry manure and chemical fertilizer was documented. Simply the unitary method of calculation was used to compare the economics of using poultry manure and chemical fertilizer in agriculture. The data on nutrient content of poultry manure and chemical fertilizers was obtained through the review of relevant publications in journal, books; and price was known through the market survey and review of annual report of Agricultural Input Company Limited (AICL).

\section{Determination of factors affecting the use of poultry manure in agricultural production}

A probit regression model was used to study the effect of different socio-economic and farm characteristics on decision to use poultry manure for agricultural production. Probit model have been used in many studies investigating the factors influencing the adoption of improved technology (Hattam, 2006). The characteristic feature of probit models is that the effect of independent variables on dependent variables is non-linear. It is a statistical model which aims to form a relation between 
probability values and explanatory variables and to ensure that the probability value remains between 0 and 1. Software package STATA (Version 16) was used for statistical analysis.

The probit model specified in this study to analyze factors affecting farmers' decisions towards use of poultry manure for agricultural production is:

$\operatorname{Pr}$ (using poultry manure $=1)=f\left(b_{0}+b_{1} X_{1}+b_{2} X_{2}+b_{3} X_{3}+b_{4} X_{4}+b_{5} X_{5}+b_{6} X_{6}+b_{7} X_{7}+b_{8} X_{8}\right.$ $\left.+\mathrm{b}_{9} \mathrm{X}_{9}+\mathrm{b}_{10} \mathrm{X}_{10}\right)$

where,

$\operatorname{Pr}=$ Probability score of using poultry manure

$\mathrm{X}_{1}=$ Family type ( dummy)

$\mathrm{X}_{2}=$ Number of schooling years (years)

$\mathrm{X}_{3}=$ Farm size (kattha)

$\mathrm{X}_{4}=$ Livestock holding (Livestock Standard Unit)

$\mathrm{X}_{5}=$ Gender of household head (Dummy)

$\mathrm{X}_{6}=$ Age of HH head (yrs)

$\mathrm{X}_{7}=$ Availability of credit (Dummy)

$\mathrm{X}_{8}=$ Major occupation (Dummy)

$\mathrm{X}_{9}=$ Annual household income income (NRs)

$\mathrm{X} 10=$ Ethnicity (Dummy)

$\mathrm{b}_{1}, \mathrm{~b}_{2 \ldots}, \mathrm{b}_{10}=$ Probit coefficient

$\mathrm{b}_{0}=$ Regression coefficient

\section{Perception of farmer towards use of poultry manure}

To explore the perception of farmers towards use of poultry manure, an interview schedule was designed. Perception regarding reasons for using poultry manure and suggestions on economic aspects (willingness to pay) and institutional aspects (who should produce) was assessed. Contingent valuation method (referendum/direct question) was asked; how much exactly you are willing to pay for poultry manure if developed as a complete fertilizer for agricultural production? Contingent valuation method was used in the United States asking the direct referendum question to analyze consumer acceptance of genetically modified foods (Kaneko and Chern, 2003a). Descriptive statistics such as frequency, percentage, mean, standard deviation were used to describe the willingness to pay for poultry manure. Software package SPSS (Version 16) was used for statistical analysis.

Indexing was done to rank (a) the reasons for using poultry manure and (b) the suggestions regarding production of processed poultry manure which could then substitute chemical fertilizers in Nepal. A scaling technique, which provides the direction and extremity attitude of the respondent towards any proposition (Miah, 1993) was used to construct the index. The intensity/ severity of the problems was ranked using the scale values $1,1-1 / n, 1-2 / n, 1-3 / n$ and so on where $n=$ number of categories in the ranking.

The formula used to determine the index for intensity of various suggestions/ reasons is,

$\mathbf{I}_{\text {sugg }}=\sum \mathbf{S}_{\mathbf{i}} \mathbf{f}_{\mathbf{i}} / \mathbf{N}$

where,

$I_{\text {sugg }}=$ index value for intensity of suggestions/reasons

$\sum=$ summation

$\mathrm{S}_{\mathrm{i}}=$ scale value at $\mathrm{i}^{\text {th }}$ intensity/severity

$f_{i}=$ frequency of the $i^{\text {th }}$ severity

$\mathrm{N}=$ total no. of the respondents $=\sum \mathrm{f}_{\mathrm{i}}$

and, 
$\mathrm{I}_{\text {sugg }}=$ index, $0<\mathrm{I}<1$

Scaling was done using the software package Microsoft Excel.

\section{Problems of using poultry manure in agricultural production}

Similarly opinions regarding nutrient loss, timely availability, were asked to the respondents and ranked on the basis of their priority to different problems. Indexing/scaling technique was again used to construct an index. Scaling techniques provide the direction and extremity attitude of the respondents towards any proposition (Miah,1993). The intensity of the problems were again ranked using the scale values $1,1-1 / \mathrm{n}, 1-2 / \mathrm{n}, 1-3 / \mathrm{n}$ and so on.

\section{RESULTS AND DISCUSSION}

\section{Economics of using poultry manure and chemical fertilizer in agricultural production}

Nitrogen, phosphorus and potassium concentration in poultry manure was found to be $1.6 \%$, $0.8 \%$ and $1.2 \%$ respectively; in addition, organic matter content close to $48 \%$ (Joshi, 2013).

Price of poultry manure per $100 \mathrm{~kg}=$ NPR. 275 (Field survey, 2013)

This means with NPR. ${ }^{1} 275 ; 1.6 \mathrm{~kg}$ nitrogen, $0.8 \mathrm{~kg}$ phosphorus, $1.2 \mathrm{~kg}$ of potash and $48 \mathrm{~kg}$ of organic matter can be obtained in using poultry manure for agricultural production; total NPK availability being $3.6 \mathrm{~kg}$. On the other side, using chemical fertilizer in agricultural production, the assessment could be proceeded as:

Nitrogen content in urea, phosphorus content in DAP (Di-ammonium phosphate) and potassium content in MOP (Mureate of potash) are reported to be $45 \%, 46 \%$ and $60 \%$ respectively (Reddy, 2007).

The imported price of urea, DAP and MOP that the Nepalese government pays was reported to be NPR.41, 56 and 42 respectively (AICL, 2013).

In this respect,

To get $1.6 \mathrm{~kg}$ of nitrogen from urea, it costs $(41 * 1.6 / 0.45)=$ NPR. 146

Similarly, to get $0.8 \mathrm{~kg}$ of phosphorus from DAP, it costs $(56 * 0.8 / 0.46)=$ NPR 97

In the same way, to get $1.2 \mathrm{~kg}$ potassium from MOP, it costs $(42 * 1.2 / 0.60)=$ NPR. 84

In total, to get $3.6 \mathrm{~kg}$ of NPK from chemical fertilizer, it costs (Rs. $146+$ Rs. $97+$ Rs. 84 ) i.e. NPR. 327.

For the same amount of NPK availability $(3.6 \mathrm{~kg})$, the amount to be paid in using chemical fertilizer (Rs. 327) was comparatively higher than in using poultry manure (Rs. 275). Besides this, availability of organic matter, positive externality on soil and human health are additional advantages associated with the use of poultry manure in agricultural production. Thus, it would be more scientific for government to take initiatives in establishment of poultry-manure fertilizer industry in Nepal rather than giving continuity to import of costlier chemical fertilizers.

\section{Factors affecting the adoption of poultry manure use in agricultural production}

To identify the factors affecting the decision to use poultry manure in agricultural production, a probit model of regression was used. Among the 120 respondents, the binary response was coded as; PM users $=1$ and 0 otherwise. The wald test $\left(\mathrm{LR} \mathrm{chi}^{2}\right)$ for the model indicated that the model has good explanatory power at the $1 \%$ level. This means that all the explanatory variables included in the model jointly influence farmer's probability of adoption of poultry manure for agricultural production. The probit model estimation gave a pseudo $\mathrm{R}^{2}$ of 0.44 which implies that the variables included in the

\footnotetext{
${ }^{1}$ NPR means Nepalese price in Ruppees; 1 \$ equivalent to 94 NPR
} 
model are able to explain about 44 percent of the probability of farm household's decisions to adopt or not to adopt poultry manure use for agricultural production. The measure of goodness of fit here concluded that the probit model employed had integrity and hence is appropriate.

Probit regression analysis showed that five variables were statistically significant for the decision to adopt poultry manure use in agricultural production. They were; age, annual household income, access to credit, membership of organization/co-operatives and major occupation (Table 1). For the interpretation of the model, marginal effects were driven from the regression coefficients, calculated from the partial derivatives as a marginal probability. The interpretation is shown in Table 1.

Table 1. Factors affecting the adoption of poultry manure use in agricultural production

\begin{tabular}{llllll}
\hline Variables & Coefficients & $\mathrm{P}>|\mathrm{z}|$ & Standard error & $\mathrm{dy} / \mathrm{dx}^{\mathrm{b}}$ & $\mathrm{S.E}^{\mathrm{b}}$ \\
\hline Age (years) & $.0526152^{* * *}$ & 0.010 & .0204978 & .0209618 & .00817 \\
Farm size / size of cultivated land (kattha) & .0293932 & 0.320 & .029534 & .0117102 & .01176 \\
Annual household income (rupees) & $.0000123^{* * *}$ & 0.001 & 0.00000358 & 0.00000492 & .00000 \\
LSU (Livestock Standard unit) & -.0238673 & 0.750 & .0748147 & -.0095087 & .0298 \\
Access to credit (yes=1) & $.7470269 * *$ & 0.050 & .3806636 & .2887314 & .1368 \\
Member of any organisation, Cooperative/ & $.6103255^{*}$ & 0.071 & .3374755 & .2391457 & .12823 \\
producer's group (yes=1) & $1.332514 * * *$ & 0.003 & .4544559 & .4807129 & .13023 \\
Major occupation (Ag.=1) & -.4123775 & 0.282 & .383115 & -.1615903 & .14577 \\
Ethnicity (Br.Ch=1) & -.3154062 & 0.494 & .461347 & -.1237789 & .17678 \\
Gender (Male=1) & .5674631 & 0.217 & .4601181 & .2217533 & .17155 \\
Family type (nuclear =1) & -6.259911 & 0.000 & 1.37289 & - & - \\
Constant & & &
\end{tabular}

*** Significant at 1\% level;** Significant at 5\% level ; * Significant at $10 \%$ level

${ }^{b}$ Marginal change in probability evaluated at the sample means

\begin{tabular}{ll}
\hline Summary Statistics & \\
\hline Number of observation(N) & 120 \\
Log likelihood & -46.581034 \\
LR chi' ${ }^{2}(1)$ & $73.19 * * *\left(\right.$ Prob $\left.>\mathrm{chi}^{2}=0.0000\right)$ \\
Pseudo $\mathrm{R}^{2}$ & 0.4400 \\
Predicted probability(adoption) & 0.5208473 \\
\hline Goodness of fit test & Pearson $\mathrm{chi}^{2}(108)=93.02$. Prob $>\mathrm{chi}^{2}=0.8473$ \\
\hline
\end{tabular}

Source: Field survey, 2013

Age of the household head was found to be highly significant and positively related to the adoption of poultry manure use in agricultural production at $1 \%$ level of significance. With the increase in age of the household head by one year, the probability of adopting poultry manure use in agriculture increases by $2 \%$ (Table 1 ).

Annual household income was positively and significantly related to the adoption of poultry manure in agriculture. A unit increase in annual household income would increase the probability of adoption of poultry manure use in agricultural production by $0.0005 \%$ at $1 \%$ level of significance (Table 1).Gbetibouo (2009) and Deresaet al. (2009) also supported the argument that increase in 
annual household income increases the probability of adoption of new technology as they have greater ability to bear risk and are in a better position to adopt new technology.

The probability of adoption increases by $48 \%$ for the farmers whose major occupation is agriculture at $1 \%$ level of significance as compared to the farmers having their major occupation other than agriculture (Table 1). As poultry manure is used as fertilizer in agricultural production, it is not surprising that the probability of using poultry manure in agriculture is higher among the farmers having their major occupation in agriculture than otherwise.

Access to credit (dummy) was found to be significant and positively related to the adoption of poultry manure use in agricultural production at 5\% level of significance. The probability of adoption of poultry manure use in agriculture increases by $28 \%$ for the farmers having access to credit as compared to farmers not having credit access (Table 1). In like manner, Yirga (2007) and Pattanayaket al. (2003) reported that availability of credit was found to be positively related to the adoption of agricultural technology.

For farmers as member of any organisation, the probability of adoption of poultry manure increases by $23 \%$ as compared to farmers having no membership (at $10 \%$ level of significance) (Table 1).Shingiet al. (1973) also stated that there is positive relationship between social participation and adoption behaviour of farmers regardless of their education status.

\section{Perception of farmers towards use of poultry manure in agricultural production Reasons for using poultry manure in agricultural production}

The farmers ranked improvement in soil fertility as the first priority or reason for using the poultry manure. Miller et al. (1991) also stated poultry manure as a valuable amendment for rice soils. Farmers ranked affordable price of poultry manure and growing poultry industry as securing the availability as second and third options respectively. Poultry manure being produced on a large scale in commercial poultry farm it is available at a cheap price (NPR 2.75 per $\mathrm{kg}$ ) due to competition between the farms. Acquaintance with the scope of bio-fertilizers was the fourth reason as ranked by farmers (Table 2).

Table 2. Reasons for using poultry manure in agricultural production

\begin{tabular}{lll}
\hline Reasons & Index value & Rank \\
\hline Improvement in soil fertility & 0.90 & I \\
Affordable price of poultry manure & 0.67 & II \\
Growing poultry industry securing the availability & 0.65 & III \\
Acquaintance with the scope of bio-fertilizers & 0.28 & IV \\
\hline
\end{tabular}

Source: Field survey, 2013

\section{Suggestions regarding who should produce the processed poultry manure}

Farmers were asked who should take the ownership to produce processed poultry manure in Nepal. The government sector was ranked first as their suggestion regarding taking the ownership of processed poultry manure production (Table 3). This first priority to government could be due to the expectation of a subsidy; as the Government of Nepal is currently giving a subsidy on chemical fertilizers. The private commercial sector was ranked second as an alternative to government; perhaps it may be due to the success history of private commercial poultry farms and rapid growth of private 
poultry industries in Nepal. The Co-operatives and small scale industries were ranked third regarding taking production ownership (Table 3).

Table 3. Suggestions regarding who should produce processed poultry manure

\begin{tabular}{lll}
\hline Suggestions & Index value & Rank \\
\hline Government sector & 0.81 & I \\
Commercial private sector & 0.66 & II \\
Co-operatives and local level small scale industries & 0.52 & III \\
No matter whoever produce, production need to be assured & 0.51 & IV \\
\hline
\end{tabular}

Source: Field Survey, 2013

\section{Willingness To Pay (WTP) for poultry manure}

Responses regarding Willingness to Pay (WTP) for processed poultry manures were taken from 60 poultry manure users who were using the raw poultry manure in agricultural production. The mean WTP was found to be NPR 15/kg, maximum and minimum being NPR 25 and NPR 10 respectively. The average price of raw poultry manure that the farmers are paying was found to be NPR $2.7 / \mathrm{kg}$.

The majority of the farmers are willing to pay between NPR 11 to Rs 19 , which is nearly 4 to 7 times more than what they are paying at present for raw poultry manure. This shows the strong positive attitude of the farmers in using processed poultry manure as an alternative to chemical fertilizer, even though the price is 4 to 7 times greater than the present price for raw poultry manure. Also, the farmers of Fulbari had showed comparatively higher willingness to pay than Mangalpur (Table 4).

Table 4. Willingness to Pay (WTP) for processed poultry manure

\begin{tabular}{llll}
\hline \multirow{2}{*}{ WTP*2 } & \multicolumn{2}{l}{ Poultry Manure Users } & Total \\
\cline { 2 - 3 } & Fulbari & Mangalpur & $14(23.3)$ \\
\hline$<$ Rs.11 & $5(16.7)$ & $9(30.0)$ & $31(51.7)$ \\
Rs.11- Rs.19 & $17(56.7)$ & $14(46.7)$ & $15(25.0)$ \\
$<$ Rs.19 & $8(26.6)$ & $7(23.3)$ & $60(100.0)$ \\
\hline Total & $30(100.0)$ & $30(100.0)$ & \\
\hline
\end{tabular}

Figures in parentheses indicate percentage

Source: Field Survey, 2013

\section{Problems/Constraints of using poultry manure for agricultural production Problems regarding nutrient loss from poultry manure}

From the survey conducted among the poultry manure users, volatization was ranked as the major problem followed by leaching, when questioned about the nutrient losses from poultry manure. According to farmers, they prioritize the effect of sunlight followed by water being the major causes of nutrient loss from poultry manure (Table 5). The perception of farmers is in the line of the findings of Wolf et al. (1988), who stated that the much nutrient is lost from poultry manure by volatization. No proper decomposition and storage loss were the third and fourth problems as per 
farmer's ranking. Beegle (1990) and Simpson (1991) also reported that the release rate of organically bounded nitrogen and phosphorus is slow due to slower mineralization of nutrients. Besides this, it is reported that some nitrogen is lost from the poultry manure in the form of ammonia, even during the storage (Wolf et al., 1988).

Table 5. Problems regarding nutrient loss from poultry manure

\begin{tabular}{lll}
\hline Problems & Index value & Rank \\
\hline Volatization (effect of air and sunlight) & 0.95 & I \\
Leaching (effect of water) & 0.65 & II \\
No proper decomposition in soil & 0.53 & III \\
Storage loss & 0.38 & IV \\
\hline
\end{tabular}

Source: Field Survey, 2013

\section{Problems regarding the availability of poultry manure to farmers}

The ranking of the problems regarding the poultry manure availability as per the perception of the respondents in the study area is presented in table 6.The problem of transportation to small scale farmers was ranked as the first problem. This problem may have been prioritized by farmers due to the higher cost of transportation associated with the small quantity of poultry manure required for their farm.From table 6, looking at the second, third and fourth rankings of the problems, it can be concluded that the farmers are facing problems with quality and quantity, recommended doses and assured markets in using poultry manure for agricultural production.

Table 6. Problems regarding availability of poultry manure to farmers

\begin{tabular}{lll}
\hline Problems & Index value & Rank \\
\hline Problem of transportation of poultry manure to farm & 0.78 & I \\
Problem of getting good quality and required quantity & 0.75 & II \\
No recommendation of dose and quantity to be applied & 0.57 & III \\
Lack of permanent/fixed market place to assure availability & 0.40 & IV \\
\hline
\end{tabular}

Source: Field Survey, 2013

\section{CONCLUSION}

Poultry manure was found to be a potential substitute for chemical fertilizers in Nepal; high nutrient status, economic viability and high willingness for use being its strength. Besides an appropriate waste management technique, use of poultry manure for agricultural production could solve the fertilizer deficit situation existing in Nepal. Also, use of poultry manure as fertilizer in agricultural production was found to be more economical than using chemical fertilizer. The government should provide credit facilities and technical assistance to the farmers for adopting new agricultural technology. Farmer's group should be formed in the VDC; this facilitates the membership to every farmer which will promote the innovation-adoption process. Volatization, leaching, transportation problems, bad smell and difficulties in intercultural operation were identified as the major problems associated with the use of raw poultry manure in agricultural production. These problems should be

${ }^{2}$ Mean NPR 15 \& SD NPR 4 for willingness to pay 
addressed, perhaps through processing and granulation, and there is a good scope for use of processed poultry manure fertilizer in Nepal. Either the government or the commercial private sector should take the initiative in production of fertilizers using the poultry manure; farmers have shown high Willingness to Pay (4 to 7 times more than current price of raw poultry manure) for use of processed poultry manure fertilizer in agriculture.

\section{ACKNOLEDGEMENTS}

We are thankful to Dean, IAAS; Academic Dean, IAAS; PSLP Project, Colleagues, seniors, juniors, respondents of Fulbari and Mangalpur VDCs for valuable and genuine information and my family for their love and inspiration. Last but not least goes to AusAID/PSLP for providing fund to conduct this research.

\section{REFERENCES CITED}

AICL. 2012. Demand and Supply of Fertilizers in 2012. Agricultural Input Company Limited, Kuleshwor, Kathmandu, Nepal.

AICL. 2013. Annual report. Agricultural Input Company Limited, Kuleshwor, Kathmandu, Nepal.

Beegle, D.B. 1990. Manure nutrient management plans for crops. Proc. 1990.National Poultry Waste Management Symposium. pp. 214-220.

Bhattarai, T.C. 2012a. Present situation of poultry population and poultry manure production in Nepal. Paper Presented in group meeting seminar on biofertilizer, PSLP Project held on $17^{\text {th }}$ July, 2012 at Hotel Royal Century, Chitwan, Nepal.

Deressa, T.T., R.M. Hassan, C. Ringler T. Alemu and M. Yusuf. 2009. Determinants of farmer's choice of adaptation methods to climate change in the Nile Basin of Ethiopia. Global Environment Change doi: 10.1016/j.gloenvcha.2009.01.002.

Ewulo, B.S. 2005. Effect of poultry and cattle manure on sandy clay loam soil. Journal of Animal Veterinary Sci.4: 839-841.

Gbetibouo, G.A. 2009. Understanding farmer's perceptions and adaptations to climate change and variability.The case of Limpopo Basin, South Africa.IFPRI Discussion Paper 00849. Environment and production Technology Division. International Food Policy Research Institute.Available at: www.ifpri.org/pubs/ otherpubs.htm\#dp (Retrieved on $12^{\text {th }}$ January 2013).

Hattam, C. 2006. Adopting organic agriculture: An investigation using the theory of planned behaviour. Poster paper prepared for presentation, International Association of Agriculture Economics Conference, Gold Coast, Australia.

Joshi, T.N. 2013.Study of poultry waste disposal through composting and vermin-composting in terms of nutrient availability, biodegradability and mineralization in Chitwan, Nepal.M.Sc. thesis.Tribhuvan University, IAAS, Chitwan, Nepal.

Kaneko, N., and W. S. Chern. 2003 a. Consumer acceptance of genetically modified foods: a telephone survey. Consumer Interests Annual 49:1-13.

Miah, A.Q. 1993. Applied statistics: A course handbook for human settlements planning. Asian Institute of Technology, Division of Human Settlements Development, Bangkok, Thailand. $412 \mathrm{p}$.

Miller, D.M., B.R. Wells, R.J. Norman, and T. Alvisyahrin. 1991. Response of lowland rice to inorganic and organic amendments on soils disturbed by grading in eastern Arkansas. In: T.C. 
Keisling, ed., Proceedings of the 1991 Southern Conservation Tillage Conference, Arkansas Agricultural Experiment Station, Fayetteville, AR. pp. 57- 61.

MOAD.2012. Statistical Information on Nepalese Agriculture. Ministry of Agricultural Development, Hariharbhawan, Kathmandu, Nepal.

Pattanayak, S.K., D.E., E. Sills and Y. JuiChen. 2003. Taking stock of agroforestry adoption studies, Agro Forestry System 57 (3): 173-186.

Reddy, S.R. 2007.Principles of Agronomy. ${ }^{\text {rd }}$ revised edition.Kalyani Publishers, New Delhi, India.

Ryan, O. and A. Pant. 2011. IFC Builds Farming Capacity in Nepal.New Business Age Nov- Dec.

Samriddhi. 2011. Commercialization of agriculture in Nepal. Discussion Paper.Samriddhi publication.

Sharma, A.K., 2001. A handbook of organic farming, Agrobios (India), Jodhpur.

Shingi, P.M., F.C. Fliegel and J.E. Kivlin. 1973. Literacy, alternative links with the larger society, and agricultural development. Behavioural Sciences and Community Development 7: 49-57.

Simpson, T.W. 1991. Agronomic use of poultry industry waste. Poultry Science 70: 1126-1131.

Thapa, P.J. 2013.Fertilizer Opportunities. The Himalayan Times Perspectives. January 3, 2013.

Tripathi, B. P. 2002. Review of acid soil and its management in Nepal. In: Proceedings of the Third National Conference on Science and Technology. Nepal Academy of Science and Technology. Lalitpur, Kathmandu, Nepal. pp. 48-60.

Wolf, D.C., J.T. Gilmour, and P.M. Gale. 1988. Estimating potential ground and surface water pollution from land application of poultry litter-Part II. Publication No. 137, Arkansas Water Resources Research Center, Fayetteville, AR.

Yigra, C.T. 2007.The dynamics of soil degradation and incentives for optimal management in Central Highlands of Ethiopia.Unpublished Ph. D Thesis. University of Pretoria, South Africa. 